\title{
An Analysis on General Self-Efficacy Beliefs of Swimming Referees in Terms of Demographic Variables
}

\author{
Canan Gulbin Eskiyecek ${ }^{1}$, Omer Satici ${ }^{2}$, Huseyin Nasip Ozaltas ${ }^{3}$, Yuksel Savucu ${ }^{4} \&$ Mine Gul $^{5}$ \\ ${ }^{1}$ School of Physical Education and Sport, Mardin Artuklu University, Mardin, Turkey \\ ${ }^{2}$ Faculty of Medical, Dicle University, Diyarbakir, Turkey \\ ${ }^{3}$ School of Physical Education and Sport, Dicle University, Diyarbakir, Turkey \\ ${ }^{4}$ Faculty of Sport Science, Kocaeli University, Elazig, Turkey \\ ${ }^{5}$ Faculty of Sport Science, Kocaeli University, Kocaeli, Turkey \\ Correspondence: Canan Gulbin Eskiyecek, School of Physical Education and Sport, Mardin Artuklu University, \\ Mardin, Turkey. E-mail: cgulbineskiyecek@gmail.com
}

Received: August 30, 2019

Accepted: September 20, 2019

Online Published: September 27, 2019

doi:10.5539/jel.v8n5p259

URL: https://doi.org/10.5539/jel.v8n5p259

\begin{abstract}
The purpose of this study is to investigate the general self-efficacy beliefs of licensed swimming referees who actively serve in Turkish Swimming Federation in terms of variables age, gender, educational status, level of referee, the reason to become a referee, professional experience and satisfaction level. The population of the study is composed of a total of 450 swimming referees participating to the Swimming Referee Development Seminar in Antalya in 2016. In addition, the research sample is randomly selected by 212 swimming referees (6 FINA, 74 National and 132 Provincial referees) including 95 females and 117 males were selected in this seminar. A five-point likert-scale "General Self-Efficacy Scale (GSES)", which was developed by Sherer et al. (1982), presented by Magaletta and Oliver (1999) as 17 items and adapted into Turkish culture by Yıldırım and İlhan (2010), was used in the study as data collection tool. Necessary formal permissions were obtained from Turkish Swimming Federation for the scale applied to the referees. Descriptive statistics, reliability analysis, factor analysis, an independent samples $t$ test, one-way analysis of variance (ANOVA) and Post-Hoc test (Tukey HSD) were applied to data by using SPSS Statistics. An analysis with $\mathrm{p}<0.05$ is considered statistically significant. Cronbach Alpha value was calculated as .949 for the scale. As a result of factorial analysis, two factors with an eigenvalue greater than one were obtained, and it was observed that these two factorial structures revealed $62.63 \%$ of the total variance. In addition, according to Bartlett's test, this test was considered significant $(p<0.05)$. As a result of the study, it was found that the swimming referees showed significant differences in terms of the variables of general self-efficacy beliefs such as level of referee, the reason to become a referee, professional experience and satisfaction level and it can be said that these variables are the determinants of the self-efficacy beliefs of swimming referees.
\end{abstract}

Keywords: swimming, referee, general self-efficacy, self-efficacy belief

\section{Introduction}

Referee is an individual who adopts the human psychology and sociology of society with his quality lifestyle, honest personality, and can interpret the individual and social attitudes of the human being and should be an example with his actions before, during and after the competition (Çimen, 2007).

The concept of self-efficacy is the belief of individuals in their ability to control over difficult demands and their own functions, in other words the ability of the person to successfully complete something (Luszczynska Luszczynska, Diehl, Gutierrez-Dona, Kuusinen, \& Schwarzer, 2004; Bandura, 1994), and this concept plays a central role in the regulation of emotional states (Bandura, 1997). In other words, competence belief, which is one of the most important concepts of social learning theory, is defined as an organization of the behaviors required to perform, and the belief of one's own abilities to perform these behaviors (Bandura, 1986).

Self-efficacy, among other factors, affects which difficulties people decide to face and how high they set their goals. Individuals with high self-efficacy in a specific field choose more challenging and assertive goals. High 
self-efficacy not only improves one's goal setting, but also makes him more persistent in maintaining his or her goal. Therefore, self-sufficient individuals have stronger goals (Luszczynska et al., 2005).

The self-efficacy of a referee is defined as an individual capable of performing the service of referee (Guillén \& Feltz, 2011). According to Bandura (1997), referee self-efficacy is the belief that a person has ability to successfully perform the necessary attitudes that may lead to the expected results in a sports branch, and the ability to perform successfully at various levels. The sense of self-efficacy can help referees to perform their duties correctly and to increase their confidence by adding more positive feelings (Nazarudin, Omar-Fauzee, \& Din, 2014). On the contrary, lack of self-efficacy may cause distraction, errors in decision making, delayed reactions and possible stress and burnout (Guillén \& Feltz, 2011).

As a result, a better understanding of self-efficacy processes can help to develop adequate intervention programs that can improve outcomes such as accuracy/speed of decisions, greater satisfaction and stability in gaining experience, less stress, and fewer errors (Lirgg, Feltz, \& Merrie, 2016). Increasing positive affective responses in terms of referees' satisfaction level should be at the center of intervention programs that further enhance the referee's protection (Diotaiuti, Falese, Mancone, \& Purromuto, 2017).

The general self-efficacy of the referees is very important for the swimming referees to understand and improve themselves and to make the competitions as successful as possible. Therefore, it is expected that the referees who are of vital importance in almost all of organized sporting events will be self-sufficient and individuals with self-efficacy in terms of managing the competition in a harmonious and disciplined manner. In this context, it is aimed to examine the general self-efficacy beliefs of licensed swimming referees, who actively serve in Turkish Swimming Federation in terms of some demographic variables (age, gender, educational status, level of referee, the reason to become a referee, professional experience and satisfaction level).

\section{Method}

\subsection{The Population and Sample of the Study}

The population of the study is composed of a total of 450 swimming referees participating to the Swimming Referee Development Seminar in Antalya in 2016. The research sample is randomly selected by 212 swimming referees (6 FINA, 74 National and 132 Provincial referees) including 95 females and 117 males were selected in this seminar.

\subsection{Methods of Data Collection}

A five-point likert-scale "General Self-Efficacy Scale (GSES)", which was developed by Sherer et al. (1982), presented by Magaletta and Oliver (1999) as 17 items and adapted into Turkish culture by Yildırım and İlhan (2010), was used in the study as data collection tool.

Intervals in the 5-point Likert scale were determined with the formula $4 / 5=0.80$. According to this, $1.00-1.80$ (None), 1.81-2.60 (Very Little), 2.61-3.40 (Sufficient), 3.41-4.20 (Good), 4.21-5.00 (Very Good) were scored.

In this context, the research data were obtained from the questionnaire, "An Analysis on General Self-Efficacy Beliefs of Swimming Referees". Necessary formal permissions were obtained from Turkish Swimming Federation for the scale applied to the referees. The questionnaire in the research were conducted by the researcher personally and the respondents were asked to choose one single answer. Cronbach's alpha value $(\alpha)$ was calculated as .949 for whole scale.

\subsection{Statistical Analysis of Data}

In the study, descriptive statistics, reliability analysis, factor analysis, independent samples t test, one-way analysis of variance (ANOVA) and Post-Hoc (Tukey HSD) test were applied to the data obtained from the scale from the scale by using SPSS 24 statistical package program. The level of significance was determined as $\mathrm{p}<0.05$.

\section{Results}

The findings related to the study are presented and evaluated in the tables below. 
Table 1. Percentage frequency distribution of demographic information of swimming referees participated in the study

\begin{tabular}{|c|c|c|c|}
\hline Variables & Subcategories & Frequency (f) & Percentage (\%) \\
\hline \multirow[t]{5}{*}{ Age } & 22 years and under & 13 & 6.1 \\
\hline & $23-26$ years & 35 & 16.5 \\
\hline & $27-30$ years & 33 & 15.6 \\
\hline & $31-34$ years & 16 & 7.5 \\
\hline & 35 years and above & 115 & 54.2 \\
\hline \multirow[t]{2}{*}{ Gender } & Female & 95 & 44.8 \\
\hline & Male & 117 & 55.2 \\
\hline \multirow[t]{5}{*}{ Educational Status } & High School & 51 & 24.1 \\
\hline & Bachelor's Degree & 106 & 50 \\
\hline & Associate Degree & 34 & 16 \\
\hline & Master's Degree & 20 & 9.4 \\
\hline & Doctorate & 1 & 0.5 \\
\hline \multirow[t]{3}{*}{ Level of Referee } & Provincial Referee & 132 & 62.3 \\
\hline & National Referee & 74 & 34.9 \\
\hline & FINA & 6 & 2.8 \\
\hline \multirow[t]{7}{*}{ Professional Experience } & $1-3$ years & 74 & 34.9 \\
\hline & $4-6$ years & 40 & 18.9 \\
\hline & $7-9$ years & 14 & 6.6 \\
\hline & $10-12$ years & 19 & 9 \\
\hline & $13-15$ years & 11 & 5.2 \\
\hline & $16-18$ years & 8 & 3.8 \\
\hline & 19 years and above & 46 & 21.7 \\
\hline \multirow[t]{5}{*}{ The Reason to Become a Referee } & Social Activity & 64 & 30.2 \\
\hline & Popularity & - & - \\
\hline & Ex-swimmer & 32 & 15.1 \\
\hline & Additional Work & 7 & 3.3 \\
\hline & Passion & 109 & 51.4 \\
\hline \multirow[t]{3}{*}{ Satisfaction Level } & Satisfied & 205 & 96.7 \\
\hline & Undecided & 7 & 3.3 \\
\hline & Not Satisfied & - & - \\
\hline Total & & 212 & 100 \\
\hline
\end{tabular}

$44.8 \%$ of the research group were female and $55.2 \%$ of those were male, $52.4 \%$ of the research group were married and $47.6 \%$ of those were single referees. When the demographic information of the research group is examined, it is seen that $54.2 \%$ of the participants were 35 years of age and older, $62.3 \%$ of the participants were provincial referee in terms of refereeing levels, $34.9 \%$ of the participants had $1-3$ years professional experience, $21.7 \%$ of the participants had more than 19 years professional experience. When educational statuses of participants are considered, it is also observed that $50 \%$ of the participants completed associate degree. In addition, $51.4 \%$ of the participants serve as a referee because they refereeing as passion and $96.7 \%$ of them are satisfied to become a referee (Table 1).

\section{Factor Analysis:}

\begin{tabular}{llll}
\hline Factor & Eigenvalue & Variation (\%) & Description \\
\hline F1 & 9.509 & 55.9 & Hasty, low self-confidence, delayed \\
F2 & 1.137 & 6.7 & Deferrer, obstinate, determined \\
Total & 62.63 & The described part of the swimming referee \\
\hline Sub-factors of F1 Factor: & & \\
\hline 9- When I decide to do something, I start immediately & \\
11- I can't easily overcome unexpected problems I face & \\
16- I give up easily & \\
4- I cannot be very successful in achieving the important goals I set \\
\hline Sub-factors of F2 Factor: \\
\hline 2- One of my problems is that I can't start a job in time \\
3- If I can't do a job on the first try, I try until I succeed \\
1- When I make plans, I'm sure that I can realize them \\
\hline
\end{tabular}


As a result of factorial analysis, two factors with eigenvalues greater than 1 were obtained. The eigenvalue of the first factor was 9.509 , the explained variation was $55.9 \%$, and the eigenvalue of the second factor was 1.137 and the explained variation was $6.7 \%$. Accordingly, it was seen that the two-factor structure explained $62.63 \%$ of the total variance. Moreover, according to Bartlett's test, this test was considered significant $(p<0.05)$. The main factors forming first factor are 9, 11, 16, 4 and others, respectively and the main factors forming second factor are $2,3,1$ and other items respectively.

Table 2. One-way ANOVA test results related to the variable of refereeing level of swimming referees

\begin{tabular}{|c|c|c|c|c|c|c|}
\hline Opinion & Variables & $\mathrm{X}$ & $\mathrm{Sd}$ & $\mathrm{F}$ & $\mathrm{p}$ & Difference (LSD) \\
\hline \multirow{3}{*}{$\begin{array}{l}\text { Failure increases my } \\
\text { ambition }\end{array}$} & Provincial & 3.9394 & .88893 & & & Significant difference was found between \\
\hline & National & 4.1081 & .82042 & 3.493 & $.032 *$ & Provincial and FINA Referees, and \\
\hline & International (FINA) & 3.1667 & 1.32916 & & & National and FINA Referees \\
\hline
\end{tabular}

Note. ${ }^{*}=\mathrm{p}<0.05$.

In Table 2, it was observed that there was a significant difference between FINA referees and National referees, and FINA referees and Provincial referees in terms of opinion that "Failure increases my ambition" $(p<0.05)$.

Table 3. One-way ANOVA test results related to the variable of professional experience of swimming referees

\begin{tabular}{|c|c|c|c|c|c|c|}
\hline Opinion & Variables & $\mathrm{X}$ & $\mathrm{Sd}$ & $\mathrm{F}$ & $\mathrm{p}$ & Difference (LSD) \\
\hline \multirow{7}{*}{$\begin{array}{l}\text { I leave everything } \\
\text { incomplete }\end{array}$} & $1-3$ years & 3.4054 & 1.09693 & \multirow{7}{*}{2.602} & \multirow{7}{*}{$.019 *$} & Significant difference was \\
\hline & 4-6 years & 3.8500 & 1.02657 & & & found between $1-3$ and $4-6$ \\
\hline & 7-9 years & 3.0000 & 1.17670 & & & years, $1-3$ and $16-18$ years, 4 \\
\hline & $10-12$ years & 3.4211 & 1.01739 & & & 6 and $7-9$ years, $7-9$ and $16-18$ \\
\hline & $13-15$ years & 3.8182 & 1.07872 & & & years, $7-9$ years and 19 years \\
\hline & $16-18$ years & 4.5000 & .53452 & & & and above, $10-12$ and $16-18$ \\
\hline & 19 years and above & 3.6957 & 1.17132 & & & years \\
\hline \multirow{7}{*}{$\begin{array}{l}\text { When I decide to do } \\
\text { something, I start } \\
\text { immediately }\end{array}$} & $1-3$ years & 3.8108 & .82222 & \multirow{7}{*}{3.106} & \multirow{7}{*}{$.006^{*}$} & Significant difference was \\
\hline & $4-6$ years & 4.2500 & .74248 & & & found between $1-3$ and $4-6$ \\
\hline & $7-9$ years & 3.3571 & 1.08182 & & & years, $1-3$ and $13-15$ years, 4 \\
\hline & $10-12$ years & 3.8947 & .80930 & & & 6 and $7-9$ years, $4-6$ years and \\
\hline & $13-15$ years & 4.3636 & .92442 & & & 19 years and above, $7-9$ and \\
\hline & $16-18$ years & 4.2500 & .70711 & & & $13-15$ years, $7-9$ and $16-18$ \\
\hline & 19 years and above & 3.7609 & .97033 & & & $\begin{array}{l}\text { years, and } 13-15 \text { years and } 19 \\
\text { years and above }\end{array}$ \\
\hline \multirow{7}{*}{$\begin{array}{l}\text { I give up easily if I don't } \\
\text { succeed in trying } \\
\text { something new at the } \\
\text { beginning }\end{array}$} & $1-3$ years & 3.7973 & .79346 & \multirow{7}{*}{3.156} & \multirow{7}{*}{$.006^{*}$} & Significant difference was \\
\hline & $4-6$ years & 4.0750 & .99711 & & & found between $1-3$ and $7-9$ \\
\hline & $7-9$ years & 3.2857 & .99449 & & & years, $1-3$ and $16-18$ years, 4 \\
\hline & $10-12$ years & 3.8947 & .73747 & & & 6 and $7-9$ years, $7-9$ and $10-12$ \\
\hline & $13-15$ years & 4.2727 & .78625 & & & years, $7-9$ and $13-15$ years, $7-$ \\
\hline & $16-18$ years & 4.6250 & .74402 & & & 9 and $16-18$ years, $7-9$ years \\
\hline & 19 years and above & 4.0217 & .80247 & & & $\begin{array}{l}\text { and } 19 \text { years and above, and } \\
16-18 \text { and } 10-12 \text { years }\end{array}$ \\
\hline \multirow{7}{*}{$\begin{array}{l}\text { I can't easily overcome } \\
\text { unexpected problems I } \\
\text { face }\end{array}$} & $1-3$ years & 3.7703 & .91483 & \multirow{7}{*}{2.668} & \multirow{7}{*}{$.016^{*}$} & \multirow{7}{*}{$\begin{array}{l}\text { Significant difference was } \\
\text { found between } 1-3 \text { and } 4-6 \\
\text { years, } 1-3 \text { and } 13-15 \text { years, } \\
\text { and } 4-6 \text { and } 7-9 \text { years }\end{array}$} \\
\hline & 4-6 years & 4.3500 & .76962 & & & \\
\hline & $7-9$ years & 3.7143 & 1.20439 & & & \\
\hline & $10-12$ years & 4.0526 & .77986 & & & \\
\hline & $13-15$ years & 4.3636 & .80904 & & & \\
\hline & $16-18$ years & 4.3750 & .74402 & & & \\
\hline & 19 years and above & 3.9783 & .90650 & & & \\
\hline
\end{tabular}

Note. ${ }^{*}=\mathrm{p}<0.05$.

In Table 3, it was observed that there was a significant difference between the variable of professional experience, and the referees" opinion that "I leave everything incomplete" $(\mathrm{p}<0.05)$, and this difference was observed between 3 and $4-6$ years, $1-3$ and $16-18$ years, $4-6$ and $7-9$ years, 7-9 and $16-18$ years, $7-9$ years and 19 years and above, and $10-12$ and $16-18$ years.

In Table 3, it was observed that there was a significant difference between the age variable, and the referees' 
opinion that "When I decide to do something, I start immediately" $(\mathrm{p}<0.05)$, and this difference was observed between $1-3$ and 4-6 years, 1-3 and 15-18 years, 4-6 and 7-9 years, 4-6 years and 19 years and above, 7-9 and $13-15$ years, $7-9$ and $13-15$ years, $7-9$ and $16-18$ years, $13-15$ years and 19 years and above.

In Table 3, it was observed that there was a significant difference between the age variable, and the referees' opinion that "I give up easily if I don't succeed in trying something new at the beginning" $(p<0.05)$, and this difference was observed between $1-3$ and $7-9$ years, $1-3$ and $16-18$ years, $4-6$ and 7-9 years, 7-9 and 10-12 years, 7-9 and 13-15 years, 7-9 and 16-18 years, 7-9 years and 19 years and above, and 16-18 and 10-12 years.

In Table 3, it was observed that there was a significant difference between the age variable, and the referees' opinion that "I can't easily overcome unexpected problems I face" $(\mathrm{p}<0.05)$, and this difference was observed between $1-3$ and $4-6$ years, $1-3$ and $13-15$ years, $4-6$ and $7-9$ years.

Table 4. T-test results related to satisfaction level of swimming referees

\begin{tabular}{|c|c|c|c|c|c|}
\hline Opinion & Variables & $\mathrm{X}$ & $\mathrm{Sd}$ & $\mathrm{t}$ & $\mathrm{p}$ \\
\hline \multirow[t]{2}{*}{ When I make plans, I'm sure that I can realize them } & Satisfied & 3.8634 & .90254 & 2.090 & $.038^{*}$ \\
\hline & Undecided & 3.1429 & .69007 & & \\
\hline \multirow[t]{2}{*}{ I leave everything incomplete } & Satisfied & 3.6244 & 1.10276 & 2.502 & $.013^{*}$ \\
\hline & Undecided & 2.5714 & .78680 & & \\
\hline \multirow[t]{2}{*}{ If a work seems too complicated, I won't even try it } & Satisfied & 3.8244 & .98935 & 3.312 & $.001^{*}$ \\
\hline & Undecided & 2.5714 & .78680 & & \\
\hline \multirow{2}{*}{$\begin{array}{l}\text { When I have to do something I don't like, I force myself } \\
\text { to finish it }\end{array}$} & Satisfied & 3.7122 & 1.05723 & 2.113 & $.036^{*}$ \\
\hline & Undecided & 2.8571 & .89974 & & \\
\hline \multirow[t]{2}{*}{ Failure increases my ambition } & Satisfied & 4.0000 & .88561 & 2.107 & $.036^{*}$ \\
\hline & Undecided & 3.2857 & .75593 & & \\
\hline \multirow[t]{2}{*}{ I give up easily } & Satisfied & 4.0195 & .87426 & 3.002 & $.003 *$ \\
\hline & Undecided & 3.0000 & 1.15470 & & \\
\hline
\end{tabular}

Note. ${ }^{*}=\mathrm{p}<0.05$.

When the satisfaction level of swimming referees is revealed in Table 4, it was observed that there was a significant difference between satisfied and undecided referees in terms of opinion that "When I make plans, I'm sure that I can realize them", "I leave everything incomplete", "If a work seems too complicated, I won't even try it", "When I have to do something I don't like, I force myself to finish it", "Failure increases my ambition" and "I give up easily" $(\mathrm{p}<0.05)$.

Table 5. One-way ANOVA test results related to swimming referees' reasons to become a referee

\begin{tabular}{|c|c|c|c|c|c|c|}
\hline Opinion & Variables & $\mathrm{X}$ & $\mathrm{Sd}$ & $\mathrm{F}$ & $\mathrm{p}$ & Difference (LSD) \\
\hline \multirow{4}{*}{$\begin{array}{l}\text { When I make plans, I'm } \\
\text { sure that I can realize } \\
\text { them }\end{array}$} & a. Social activity & 3.8438 & .82074 & \multirow{4}{*}{2.882} & \multirow{4}{*}{$.037 *$} & \multirow{4}{*}{$\begin{array}{l}\text { Significant difference was } \\
\text { found between } b \text { and } c \text {, and } c \\
\text { and } d\end{array}$} \\
\hline & b. Ex-swimmer & 4.1563 & .91966 & & & \\
\hline & c. Additional work & 3.1429 & .89974 & & & \\
\hline & d. Passion & 3.7890 & .92369 & & & \\
\hline \multirow{4}{*}{$\begin{array}{l}\text { Failure increases my } \\
\text { ambition }\end{array}$} & a. Social activity & 4.0469 & .84383 & \multirow{4}{*}{4.310} & \multirow{4}{*}{$.006^{*}$} & \multirow{4}{*}{$\begin{array}{l}\text { Significant difference was } \\
\text { found between a and } c, b \text { and } \\
c \text {, and } c \text { and } d\end{array}$} \\
\hline & b. Ex-swimmer & 4.2500 & .84242 & & & \\
\hline & c. Additional work & 3.0000 & 1.00000 & & & \\
\hline & d. Passion & 3.9174 & .88326 & & & \\
\hline \multirow{4}{*}{$\begin{array}{l}\text { I don't always trust my } \\
\text { skills }\end{array}$} & a. Social activity & 4.0313 & .73396 & \multirow{4}{*}{2.954} & \multirow{4}{*}{$.034 *$} & \multirow{4}{*}{$\begin{array}{l}\text { Significant difference was } \\
\text { found between a and } \mathrm{c}, \mathrm{b} \text { and } \\
\mathrm{c} \text {, and } \mathrm{c} \text { and } \mathrm{d}\end{array}$} \\
\hline & b. Ex-swimmer & 4.1875 & .89578 & & & \\
\hline & c. Additional work & 3.1429 & 1.06904 & & & \\
\hline & d. Passion & 3.9908 & .87660 & & & \\
\hline \multirow[t]{4}{*}{ I give up easily } & a. Social activity & 4.0156 & .80656 & \multirow{4}{*}{4.643} & \multirow{4}{*}{$.004 *$} & \multirow{4}{*}{$\begin{array}{l}\text { Significant difference was } \\
\text { found between a and } \mathrm{c}, \mathrm{b} \text { and } \\
\mathrm{c} \text {, and } \mathrm{c} \text { and } \mathrm{d}\end{array}$} \\
\hline & b. Ex-swimmer & 4.2188 & .70639 & & & \\
\hline & c. Additional work & 2.8571 & 1.34519 & & & \\
\hline & d. Passion & 3.9725 & .92755 & & & \\
\hline
\end{tabular}

Note. ${ }^{*}=\mathrm{p}<0.05$. 
In Table 5, it was observed that there was a significant difference between the variable of referees' reason to become a referee, and the referees' opinion that "When I make plans, I'm sure that I can realize them" $(\mathrm{p}<0.05)$, and this difference was observed between the options $\mathrm{b}$ and $\mathrm{c}, \mathrm{b}$ and $\mathrm{d}$.

In Table 5, it was observed that there was a significant difference between the variable of referees' reason to become a referee, and the referees' opinion that "Failure increases my ambition" $(p<0.05)$, and this difference was observed between the options a and $\mathrm{c}, \mathrm{b}$ and $\mathrm{c}, \mathrm{c}$ and $\mathrm{d}$.

In Table 5, it was observed that there was a significant difference between the variable of referees' reason to become a referee, and the referees' opinion that "I don't always trust my skills" $(\mathrm{p}<0.05)$, and this difference was observed between the options a and c, b and c, c and d.

In Table 5 , it was observed that there was a significant difference between the variable of referees' reason to become a referee, and the referees' opinion that "I give up easily" $(p<0.05)$, and this difference was observed between the options a and $\mathrm{c}, \mathrm{b}$ and $\mathrm{c}, \mathrm{c}$ and $\mathrm{d}$.

\section{Discussion and Conclusion}

The results obtained from the general self-efficacy beliefs of licensed swimming referees actively involved in this study were discussed within the context of the research and compared with other studies in the literature.

It was found that general self-efficacy belief levels of swimming referees showed significant differences according to the duration of the referee. There are studies supporting the findings of this research in the literature Koçak (2019) stated that there is a significant difference between the volleyball referees' self-efficacy and experience variable and that the time spent in the referee affects the referee's self-efficacy positively. Adigüzel (2018) reported that professional experience of basketball referees was an important variable on the referees' self-efficacy. Sarıdede (2018) reported that more experienced volleyball referees had significantly higher referee self-efficacy rather than less experienced referees. Similarly, Guillén and Feltz (2011) stated that professional experience had an effect on referees' self-efficacy and that experienced referees had less stress and higher self-efficacy. In contrast to this study, Dereceli et al. (2019) evaluated the general self-efficacy of football referees in terms of some variables and it was found that there was no significant relationship between experience variable and the sub-dimensions of general self-efficacy. In the light of the results in the literature, Diotaiuti et al. (2017) confirmed that experience appears to be a predictor of self-efficacy rather than age.

It was found that general self-efficacy beliefs of the referees differed significantly according to the variable of referees' level, and that FINA referees, compared to both national and provincial referees, do not give up the struggle and the desire to overcome obstacles when faced with a failure. In the study, significant findings obtained between the referees' general self-efficacy beliefs and the degree of referees were consistent with similar studies in the literature. Koçak (2019) found a significant difference between referees' level and self-efficacy. Sarıdede (2018) emphasized that as the degree of refereeing increases, the referees tend to make clearer decision.

In the study, it was found that there was no significant difference between the self-efficacy levels of swimming referees and age variable. In the literature, there are studies supporting the findings of the research. Dereceli et al. (2019) stated that there was no significant relationship between age variable and sub-dimensions of general self-efficacy of football referees. The findings in the literature differ from the results of the research. Koçak (2019) stated that there are significant differences between the referees' self-efficacy and age variable. Adigüzel (2018) reported that the age variable of basketball referees is an important variable on the referees' self-efficacy.

When studies conducted about different sample groups were examined, Uysal and Kösemen (2013) analyzed the general self-efficacy beliefs of teacher candidates in terms of some variables, and no significant difference was found in terms of age variable. Contrary to findings in the literature, Telef and Karaca (2011) examined the self-efficacy of adolescents in terms of various demographic variables and found significant differences in terms of age variable.

It was determined that there was no significant difference between general self-efficacy levels and gender of swimming referees. The study shows parallelism with other studies in the literature. Adigüzel (2018) reported that there was no significant difference between general self-efficacy levels and gender of basketball referees. Uysal and Kösemen (2013) stated that there was no significant difference between gender and general self-efficacy beliefs of teacher candidates. However, contrary to these studies, Koçak (2019), Karaçam and Pulur (2017a) and Karaçam and Pulur (2017b) found significant differences between general self-efficacy levels and gender of referees.

When the studies conducted with different sample groups were examined, Uysal (2013) investigated the effect of 
various variables of academicians on general self-efficacy and reported that there was no significant difference in terms of gender variable. However, Demirtaş et al. (2011) and Özdemir (2008) reported that self-efficacy beliefs of candidate teachers differ significantly in terms of gender variable. Telef and Karaca (2011) examined the self-efficacy levels of adolescents in terms of various demographic variables and found significant differences in terms of gender variable.

In the study, it was found that there was no significant difference between general self-efficacy levels and educational status of swimming referees. Koçak (2019), contrary to this study, found that there was a significant difference between the self-efficacy levels and educational status of volleyball referees, but this variable was not a determinant of self-efficacy level. It can be said that this difference in the literature is due to the unique structure of the sample group.

It was found that there was no significant difference between general self-efficacy levels and educational status of swimming referees. In the literature, no findings were found about these variables, but it was found that there were studies conducted with different variables and samples (Dwyer \& Cummings, 2001; Çapri et al., 2012; Karaçam \& Pulur, 2017a). Uysal and Kösemen (2013) did not find any significant difference between general self-efficacy beliefs of candidate teachers, and the variables of classroom and department. Uysal (2013) reported that there was no significant difference between the variables of title and department and general self-efficacy of academicians.

As a result of the factor analysis conducted in the study, it was found that swimming referees had two different characteristics. It was determined that $55.9 \%$ of the first group is hasty and quitter and had low self-confidence and $6.7 \%$ of the second group was deferrer, obstinate and determined. It was also considered that there are other underlying reasons why referees exhibit hasty or quitter person characteristics. These reasons may arise out of the limited structure of individual autonomy, the institutional logic of the profession of refereeing in sports, and the excessive control and discipline. In short, it was concluded that these swimming referees had "Self-Efficacy of Reference" regarding the result of any competition. It is also thought that this situation is related to the findings of the variables of educational status of the referees.

Many studies have been conducted on referees' self-efficacy and some researchers have considered the referees' self-efficacy in different dimensions. For example, Diotaiuti et al. (2017) tried to determine the factors predicting self-efficacy on handball referees and suggested that the perception of teamwork effectiveness would be an important determinant for self-efficacy of handball referees. In addition, the researchers confirmed the role of double-activity perception as a predictor for self-efficacy perception of handball referees and argued that some aspects of referee's experience such as teamwork, enjoyment, and autonomy dimensions could provide a good explanation for perceived referee self-efficacy.

When the results obtained in the study were evaluated, it was found that general self-efficacy beliefs of swimming referees showed significant differences in terms of referees' level, reason to become a referee and satisfaction level. In this context, it can be said that referees' level, reason to become a referee and satisfaction level are the determinants of the self-efficacy beliefs of swimming referees.

\section{Acknowledgments}

This paper was submitted as an oral paper at the 6th International Congress on Science, Culture and Sports held between 25th-28th April 2018 in Lviv, Ukraine.

\section{References}

Adıgüzel, N. S. (2018). Basketbol hakemlerinin fiziksel öz saygıları ile öz yeterlilikleri arasındaki ilişkinin incelenmesi. Ulusal Spor Bilimleri Dergisi, 2(2), 129-137. https://doi.org/10.30769/usbd.482410

Bandura, A. (1977). Self-efficacy: Toward a unifying theory of behavioral change. Psychological Review, 84(2), 191-215. https://doi.org/10.1037/0033-295X.84.2.191

Bandura, A. (1986). Social foundations of thought and action: A social cognitive theory. Englewood Cliffs, NJ: Prentice-Hall.

Bandura, A. (1994). Self-Efficacy. In V. S. Ramachaudran (Ed.), Encyclopedia of human behavior (vol. 4, pp. 71-81). New York: Academic Press.

Bandura, A. (1997). Self-efficacy: The exercise of control (4th ed.). New York, NY: W.H.

Bandura, A. (2002). Social cognitive theory in cultural context. Journal of Applied Psychology: An International Review, 51, 269-290. https://doi.org/10.1111/1464-0597.00092 
Çapri, B., Özkendir, M. O., Özkurt, B., \& Karakuş, F. (2012). General self-efficacy beliefs, life satisfaction and burnout of university students. Procedia - Social and Behavioral Sciences, 47, 968-973. https://doi.org/10.1016/j.sbspro.2012.06.765

Çimen, S. (2007). Ankara bölgesi klasman futbol hakemlerinin kişilik özelliklerinin incelenmesi. Gazi Üniversitesi Eğitim Bilimleri Enstitüsü, Yüksek Lisans Tezi, Ankara.

Demirtaş, H., Cömert, M., \& Özer, N. (2011). Öğretmen Adaylarının Özyeterlik İnançları ve Öğretmenlik Mesleğine İlişkin Tutumları. Ĕgitim ve Bilim, 36(159), 96-111.

Dereceli, Ç., Toros, T., \& Yıldız, R. (2019). Futbol Hakemlerinin Durumluk Kaygı ve Genel Öz Yeterlik Düzeylerinin Bazı Değişkenler Açısından İncelenmesi. Spormetre, 17(2), 64-74.

Diotaiuti, P., Falese, L., Mancone, S., \& Purromuto, F. (2017). A structural model of self-efficacy in handball referees. Front Psychol, 8, 811. https://doi.org/10.3389/fpsyg.2017.00811

Dwyer, A. L., \& Cummings, A. L. (2001). Stress, Self-Efficacy, Social Support, and Coping Strategies in University Students. Canadian Journal of Counselling (Revue canadienne de counseling I), 35, 3.

Feltz, D. (1988). Self-confidence and sports performance. Exercise Sport Science Reviews, 16, 423-457. https://doi.org/10.1249/00003677-198800160-00016

Guillén, F., \& Feltz, D. L. (2011). A conceptual model of referee efficacy. Frontiers in Psychology, 2(25), 1-5. https://doi.org/10.3389/fpsyg.2011.00025

Karaçam, A., \& Pulur, A. (2017a). Examining the relationship between referee self-efficacy and general self-efficacy levels of football, basketball and handball referees. Universal Journal of Educational Research, 5(9), 1571-1579. https://doi.org/10.11114/jets.v5i8.2450

Karaçam, A., \& Pulur, A. (2017b). Examining the relationship between referee self-efficacy and general self-efficacy levels of basketball referees in terms of certain variables. Journal of Education and Training Studies, 5(8), 37-45. https://doi.org/10.11114/jets.v5i8.2450

Koçak, Ç. V. (2019). Voleybol Hakemlerinin Hakem Öz Yeterlik Düzeylerinin İncelenmesi. Spormetre, 17(2), 33-40. https://doi.org/10.33689/spormetre.552892

Lirgg, C. D., Feltz, D. L., \& Merrie, M. D. (2016). Self-efficacy of sports officials: a critical review of the literature. Journal of Sport Behavior, 39(1), 39-50.

Luszczynska, A., Diehl, M., Gutierrez-Dona, B., Kuusinen, P., \& Schwarzer, R. (2004). Measuring one component of dispositional self-regulation: Attention control in goal pursuit. Personality and Individual Difference, 37(3), 555-566. https://doi.org/10.1016/j.paid.2003.09.026

Luszczynska, A., Scholz, U., \& Schwarzer, R. (2005). The general self-efficacy scale: Multicultural validation studies. The Journal of Psychology Interdisciplinary and Applied, 139(5), 439-457. https://doi.org/10.3200/JRLP.139.5.439-457

Nazarudin, M. N., Omar-Fauzee, M. S., \& Din, A. (2009). Malaysian rugby referees perception on the athletes, coaches, and spectators misconduct: a case study. European Journal of Social Sciences, 7(4), 102-106.

Özdemir, S. M. (2008). Sınıf Öğretmeni Adaylarının Öğretim Sürecine İlişkin Öz-Yeterlik İnançlarının Çeşitli Değişkenler Açısından İncelenmesi. Kuram ve Uygulamada Eğitim Yönetimi, 54, 277-306.

Sarıdede, Ç. (2018). Voleybol hakemlerinin öz yeterlik düzeyleri ve karar verme becerilerinin incelenmesi. İstanbul Gelişim Üniversitesi Sağlı Bilimleri Enstitüsü, Yüksek Lisans Tezi, İstanbul.

Telef, B. B., \& Karaca, R (2011). Ergenlerin Öz-Yeterliklerinin ve Psikolojik Semptomlarının İncelenmesi. Mustafa Kemal Üniversitesi, Sosyal Bilimler Enstitüsü Dergisi, 8(16), 499-518.

Uysal, İ. (2013). Akademisyenlerin Genel Öz-Yeterlik İnançları: AİBÜ Eğitim Fakültesi Örneği. Trakya Üniversitesi Ĕ̈itim Fakültesi Dergisi, 3(2), 144-151.

Uysal, İ., \& Kösemen, S. (2013). Öğretmen Adaylarının Genel Öz-Yeterlik İnançlarının İncelenmesi. Eğitim ve Öğretim Araştırmaları Dergisi, 2(2), 217-226.

\section{Copyrights}

Copyright for this article is retained by the author, with first publication rights granted to the journal.

This is an open-access article distributed under the terms and conditions of the Creative Commons Attribution license (http://creativecommons.org/licenses/by/4.0/). 